\title{
A CHLORHEXIDINE-RELEASING EPOXY-BASED COATING ON TITANIUM IMPLANTS PREVENTS STAPHYLOCOCCUS AUREUS EXPERIMENTAL BIOMATERIAL-ASSOCIATED INFECTION
}

\author{
M. Riool ${ }^{1}$, A.J. Dirks², V. Jaspers ${ }^{1}$, L. de Boer ${ }^{1}$, T.J.A. Loontjens 3 , C.M. van der $\operatorname{Loos}^{4 \dagger}$, S. Florquin ${ }^{4}$, I. Apachitei ${ }^{5}$, \\ L.N.D. Rijk ${ }^{2}$, H.A. Keul ${ }^{2}$ and S.A.J. Zaat ${ }^{1 *}$ \\ ${ }^{1}$ Department of Medical Microbiology, Center for Infection and Immunity Amsterdam (CINIMA), \\ Academic Medical Center, University of Amsterdam, Amsterdam, The Netherlands \\ ${ }^{2}$ DSM B.V., Geleen, The Netherlands \\ ${ }^{3}$ Department of Polymer Chemistry, University of Groningen, Groningen, The Netherlands \\ ${ }^{4}$ Department of Pathology, Academic Medical Center, University of Amsterdam, Amsterdam, The Netherlands \\ ${ }^{5}$ Department of Biomechanical Engineering, Delft University of Technology, Delft, The Netherlands

\section{$\dagger$ Deceased}

\begin{abstract}
Prevention of biomaterial-associated infections (BAI) remains a challenging problem, in particular due to the increased risk of resistance development with the current antibiotic-based strategies. Metallic orthopaedic devices, such as non-cemented implants, are often inserted under high mechanical stress. These non-cemented implants cannot be protected by e.g. antibiotic-releasing bone cement or other antimicrobial approaches, such as the use of bioactive glass. Therefore, in order to avoid abrasion during implantation procedures, we developed an antimicrobial coating with great mechanical stability for orthopaedic implants, to prevent Staphylococcus aureus BAI. We incorporated 5 and $10 \mathrm{wt} \%$ chlorhexidine in a novel mechanically stable epoxy-based coating, designated $\mathrm{CHX}_{5}$ and $\mathrm{CHX}_{10}$, respectively. The coatings displayed potent bactericidal activity in vitro against $S$. aureus, with over $80 \%$ of the release $\left(19 \mu \mathrm{g} / \mathrm{cm}^{2}\right.$ for $\mathrm{CHX}_{5}$ and $41 \mu \mathrm{g} /$ $\mathrm{cm}^{2}$ for $\mathrm{CHX}_{10}$ ) occurring within the first $24 \mathrm{~h}$. In mice, the $\mathrm{CHX}_{10}$ coating significantly reduced the number of CFU (colony forming units), both on the implants and in the peri-implant tissues, $1 \mathrm{~d}$ after $S$. aureus challenge. The $\mathrm{CHX}_{10}$-coated implants were well-tolerated by the animals, with no signs of toxicity observed by histological analysis. Moreover, the coating significantly reduced the frequency of culture-positive tissues $1 \mathrm{~d}$, and of culturepositive implants 1 and $4 \mathrm{~d}$ after challenge. In summary, the chlorhexidine-releasing mechanically stable epoxybased $\mathrm{CHX}_{10}$ coating prevented implant colonisation and $S$. aureus BAI in mice and has good prospects for clinical development.
\end{abstract}

Keywords: antimicrobial coating, chlorhexidine, Staphylococcus aureus, titanium, in vivo test, mouse, infection, histology.
*Address for correspondence:

Sebastian A. J. Zaat

Department of Medical Microbiology

Center for Infection and Immunity Amsterdam (CINIMA)

Academic Medical Center

University of Amsterdam, Meibergdreef 15

1105 AZ, Amsterdam, The Netherlands

Telephone number: +31 205664863

Email: s.a.zaat@amc.uva.nl

\section{Introduction}

Medical devices manufactured from titanium, such as prosthetic joints and dental implants, are widely used in modern medicine. Titanium's lightness, good mechanochemical and osseo-integrative properties make it an ideal material for bone implant application (Web ref. 1). Unfortunately, as with any inserted or implanted foreign body material (Elek and Conen, 1957; Zimmerli and Sendi, 2011), a significant problem with titanium implants is the risk of infection. These so-called biomaterial-associated infections (BAIs) are feared complications in orthopaedic and trauma surgery with tremendous consequences for the patients. The majority of BAIs are caused by staphylococci, especially Staphylococcus epidermidis and Staphylococcus aureus (S. aureus) (Anderson and Marchant, 2000; O'Gara and Humphreys, 2001). Formation of a biofilm consisting of bacteria, bacterial products and host proteins on the biomaterial surface is considered the major component in the pathogenesis of BAI (Costerton et al., 1999). In addition, the presence of the foreign body material leads to colonisation of tissue surrounding implants (Broekhuizen et al., 2008a; Engelsman et al., 2010; Nejadnik et al., 2008; Vuong et al., 2004; Zaat et al., 2010).

In order to prevent infection of medical devices, a variety of surface modifications have been developed. These include non-adhesive, contact-killing and tissueintegrating surfaces, as well as coatings for the controlled release of antimicrobial agents (Brooks et al., 2013; Busscher et al., 2012). To prevent both, colonisation of the implant itself and of the tissue surrounding the implant, an antimicrobial-releasing coating is preferred. However, the 
use of antibiotics on a medical device is discouraged by government regulatory agencies, especially the American Food and Drug Administration (FDA), in view of the increasing development of resistance (Brooks et al., 2013; FDA, 2007). As an alternative to antibiotics, commonly used antiseptics, such as chlorhexidine, might be used. Chlorhexidine (CHX) has broad antimicrobial activity and has been shown to prevent infection in patients and in animal models. It is used topically, for site preparation in surgical procedures, and also intracorporally, e.g. in abdominal surgery for rapid sterilisation of exposed tissues prior to wound closure (Wilkins and Unverdorben, 2013). Moreover, chlorhexidine is widely applied as an irrigant fluid in dentistry with low toxicity and good tolerability in soft tissue (Iqbal, 2012). In biomaterials, chlorhexidine has been applied in combination with silver-sulfadiazine in a coating on intravenous catheters, which decreases catheter-related infection in humans (Maki, 1997). Experimental titanium tibia intramedullary nails coated with chlorhexidine and chloroxylenol have reduced rates of orthopaedic device-related infection in rabbits (Darouiche et al., 1998a; Darouiche et al., 1998b).

In the present study we aimed to design an antimicrobial coating for titanium implants for general application in orthopaedics and trauma, with high mechanical stability, in order to avoid abrasion during implantation procedures. Coatings and materials manufactured from epoxy resins are among the few available that meet this requirement (Berruet et al., 1987; Garcia et al., 2009). Epoxy resins can be catalytically cross-linked or they can be cured using reagents such as polyamines. The typically good adhesion to metallic substrates and good mechanical properties of epoxy-based coatings (Foyet et al., 2009; Meis et al., 2014; Wu et al., 2014) prompted us to investigate an epoxyamine coating network containing chlorhexidine as the antimicrobial agent for orthopaedic implants. Dopamine is added to the coating because the catechol moiety of dopamine is known for its strong adhesion to a range of metallic substrates, including medical-grade titanium (Fan et al., 2006; Shi et al., 2008; Watson et al., 2010).

Therefore, the purpose of the present study was to develop an epoxy-based chlorhexidine-releasing coating for titanium implants with potent in vitro as well as in vivo antibacterial activity in a murine subcutaneous implant infection model. In this model, the release of chlorhexidine proved to be effective in preventing $S$. aureus colonisation of the implants and surrounding tissue without signs of toxicity.

\section{Materials and Methods}

\section{Coating preparation}

Coating formulations as described in Table 1 were prepared as follows. For solution A, isophorone diamine (IPD; Sigma-Aldrich $\geq 99 \%$ ) was dissolved in ethanol (EtOH) at room temperature, while stirring. Dopamine hydrochloride (dopamine; Sigma-Aldrich) was added to this solution and left stirring until completely dissolved. Next, glycerol diglycidyl ether (epoxy resin; Sigma-Aldrich, technical grade) was added to the mixture. The resulting solution A was left to stand for $1 \mathrm{~h}$ at room temperature. For solution $\mathrm{B}$, chlorhexidine diacetate salt hydrate [Sigma-Aldrich, bis(biguanide) antimicrobial] was dissolved in $\mathrm{EtOH}$ at room temperature, while stirring. For the unloaded control coatings, no chlorhexidine was added to solution B. Just prior to the coating procedures, solutions A and B were mixed. The weights of the solids used for the solutions $\mathrm{A}$ and $\mathrm{B}$ are listed in Table 1. The coating formulations were designated $\mathrm{CHX}_{0}$ (no chlorhexidine), $\mathrm{CHX}_{5}$ (5 wt \% chlorhexidine) and $\mathrm{CHX}_{10}$ (10 wt \% chlorhexidine). Two batches of the $\mathrm{CHX}_{0}$ and $\mathrm{CHX}_{10}$ coating formulations were prepared. The chemical composition was kept maximally constant in both batches with particular attention to the ratio between the amino groups and the epoxy groups determining the crosslink density. The coating formulations of $\mathrm{CHX}_{0}$ (1st batch), $\mathrm{CHX}_{5}$ and $\mathrm{CHX}_{10}$ (1st batch) were used to coat aluminium sheets and titanium disks for the in vitro assays. The second batch $\mathrm{CHX}_{0}$ and $\mathrm{CHX}_{10}$ formulations were used to coat the titanium implants for the in vivo assays. Formulations were prepared fresh prior to application to the different materials.

\section{Application of coating to aluminium sheets and titanium discs by spin-coating}

For the in vitro experiments, coatings were applied on aluminium sheets $(5 \times 5 \mathrm{~cm})$, Q-panels $(15.3 \times 10.1 \mathrm{~cm})$ and medical grade titanium [Ti 6Al-4V ELI, surface finish 2B (ASTM A480) (Web ref. 2)] discs (diameter $20 \mathrm{~mm}$, height $1 \mathrm{~mm}$ ), which had been cleaned by submerging in ethanol and acetone and subsequent treatment with ultrasound for $5 \mathrm{~min}$. Aliquots of approximately $1 \mathrm{~mL}$ and $0.1-0.2 \mathrm{~mL}$ of the coating formulation were applied to the surface of aluminium sheets and titanium disks, respectively, and the samples were spin-coated at a rotation speed of 1,000 rpm for $30 \mathrm{~s}$. The samples were air-dried for $0.5-2 \mathrm{~h}$ and subsequently placed in an oven at $\sim 90{ }^{\circ} \mathrm{C}$ for $3 \mathrm{~h}$.

\section{Application of coatings to titanium implants by dipping}

For the in vivo experiments, medical-grade titanium implants $(10 \times 4 \times 1 \mathrm{~mm}$, with a slit to allow cutting of the implant after explantation, see below) were manufactured by Flowcut (Nederweert, The Netherlands) and coated using the following procedure. First, the implants were cleaned by boiling them for $1 \mathrm{~h}$ in $10 \mathrm{wt} \%$ aqueous $\mathrm{NaOH}$, followed by ultrasonic treatment in ethanol and acetone for $5 \mathrm{~min}$. The implants were dip-coated to allow complete coverage of the surface in spite of their complex shape. The implants were connected to a paperclip and submerged completely in the dipping solution using a dip coater (Specialty Coating Systems, type PL-3201, SCS, Indianapolis, IN, USA) with a dip speed of $2 \mathrm{~mm} / \mathrm{s}$. The dipped implants were dried for $0.5-1 \mathrm{~h}$ and placed in a convection oven at $90{ }^{\circ} \mathrm{C}$ for $3 \mathrm{~h}$ for curing. The paperclip was removed and the coated implants sterilised by autoclaving at $121^{\circ} \mathrm{C}$ for $20 \mathrm{~min}$.

\section{In vitro chlorhexidine release assay}

Samples of $1 \times 5 \mathrm{~cm}$ were cut from the coated aluminium sheets and incubated with $4 \mathrm{~mL}$ of phosphate buffered 
Table 1. Coating formulation compositions. Batch 1 was used for spin-coating of the aluminium sheets, Q-panels and titanium disks; batch 2 for dip-coating of the in vivo titanium implants. To obtain a similar coating thickness in both coating procedures, the viscosity of the formulation had to be smaller in case of the dip-coating procedure and therefore a reduced solid in EtOH content was used in batch 2 .

\begin{tabular}{|c|c|c|c|c|c|c|c|c|c|c|c|c|}
\hline \multirow{3}{*}{$\frac{\text { Coating }}{\mathrm{CHX}_{0}}$} & \multirow{3}{*}{$\frac{\text { Batch }}{1}$} & \multicolumn{2}{|c|}{ EtOH (g) } & \multicolumn{8}{|c|}{ Solids (g) } & \multirow{3}{*}{$\frac{\text { NH/epoxy }}{1.04}$} \\
\hline & & Sol. A & Sol. B & \multicolumn{2}{|c|}{ Epoxy } & \multicolumn{2}{|c|}{ IPD } & \multicolumn{2}{|c|}{ Dopamine } & \multirow{2}{*}{\multicolumn{2}{|c|}{$\frac{\text { CHX }}{-}$}} & \\
\hline & & 5.00 & 10.00 & 4.993 & $(64.9 \%)$ & 1.731 & $(22.5 \%)$ & 0.969 & $(12.6 \%)$ & & & \\
\hline $\mathrm{CHX}_{5}$ & 1 & 5.00 & 10.00 & 4.992 & $(61.8 \%)$ & 1.720 & $(21.3 \%)$ & 0.969 & $(12.0 \%)$ & 0.369 & $(4.9 \%)$ & 1.03 \\
\hline $\mathrm{CHX}_{10}$ & 1 & 5.00 & 10.00 & 5.021 & $(59.0 \%)$ & 1.719 & $(20.2 \%)$ & 0.962 & $(11.3 \%)$ & 0.809 & $(9.5 \%)$ & 1.03 \\
\hline $\mathrm{CHX}_{0}$ & 2 & 10.00 & 15.00 & 5.012 & $(65.0 \%)$ & 1.740 & $(22.6 \%)$ & 0.962 & $(12.5 \%)$ & & - & 1.07 \\
\hline $\mathbf{C H X}_{10}$ & 2 & 10.00 & 15.00 & 5.012 & $(58.5 \%)$ & 1.740 & $(20.3 \%)$ & 0.962 & $(11.2 \%)$ & 0.858 & $(10.0 \%)$ & 1.07 \\
\hline
\end{tabular}

saline (PBS; $\mathrm{pH}=7.0$ ) at $37^{\circ} \mathrm{C}$, while shaking at $100 \mathrm{rpm}$. At different time points $(0,1,2,3$ and $4 \mathrm{~d})$ the medium was exchanged with fresh PBS and the chlorhexidine concentration in the removed medium was determined by ultraviolet-visible spectroscopy (UV-Vis). The absorption values at $\lambda=255 \mathrm{~nm}$ were converted to mass concentrations of chlorhexidine through a calibration curve $(\mathrm{m}=22.427 \times \mathrm{A}+0.2474$; with $\mathrm{m}$ : mass of chlorhexidine, A: measured absorbance at $\lambda=255 \mathrm{~nm}$ ) and these values were plotted against time in a cumulative way. The lower limit of detection for the absorption was $0.005 \mathrm{AU}$ (arbitrary units). In case of an absorption above 1.5 AU, the sample was diluted and measured again. The amount of chlorhexidine released at $96 \mathrm{~h}$ was defined as the total releasable amount. Percentage release at other time points was calculated based on this amount. The results of one representative experiment are shown.

\section{Mechanical stability assays}

Solvent resistant assay

A double rub test was used to assess the mechanical stability of the coatings under dry conditions. A number of the coated aluminium Q-panels were washed in PBS at $37{ }^{\circ} \mathrm{C}$ for $48 \mathrm{~h}$, to assess the mechanical stability of the coatings under wet conditions. The double rub test was performed essentially as described in the solvent resistance standard test method [ASTM D5402 (Web ref. 3)], with some modifications. In short, a piece of felt (diameter $2 \mathrm{~cm}$ ), soaked in EtOH (more appropriate solvent than methyl ethyl ketone (MEK) used in ASTM D5402), was moved back and forth (1 double rub) over a distance of $12 \mathrm{~cm}$ (in $1 \mathrm{~s}$ ) using an automated rubbing apparatus (DSM, in house equipment) on a defined area of the coated substrate with a constant load of $400 \mathrm{~g}$. When macroscopic damage to the coating was observed, the test was stopped and the number of rubs was noted. A maximum of 200 double-rubs were applied and the resistance was rated by eye on a 0 to 5 scale, with 0 meaning penetration of the substrate in 200 double rubs or less and 5 meaning no effect on surface after 200 double rubs.

\section{Tape adhesion test}

The adhesion of the coating to the substrate was tested essentially as described in the tape standard test method
[ASTM D3359 (Web ref. 4)]. Due to the coating hardness, it was not possible to make cuts as described in ASTM D3359 prior to the procedure. In short, $25 \mathrm{~mm}$ wide semitransparent pressure-sensitive tape was pressed firmly onto a defined area of the coating and pulled off rapidly under an angle close to $180^{\circ}$. The test was repeated on two other sites of the coated aluminium Q-panels and the level of adhesion was rated by eye on 0 - 5 scale, with 0 meaning full removal of the coating and 5 meaning no peeling or removal of the coating.

\section{Scanning electron microscopy}

A JEOL JSM-IT100 scanning electron microscope (SEM; JEOL, Tokyo, Japan) was used to examine non-coated and $\mathrm{CHX}_{10}$-coated titanium implants. Before imaging, specimens were sputter-coated with a carbon layer of $\sim 6 \mathrm{~nm}$ thickness. The images were collected at an acceleration voltage of $5-15 \mathrm{kV}$.

\section{Atomic force microscopy}

Atomic force microscopy (AFM) was performed with an AFM Dimension Edge (Bruker, Camarillo, CA, USA). Non-coated and $\mathrm{CHX}_{10}$-coated titanium implants were scanned in tapping mode with a standard silicon cantilever at a resonance frequency of $370 \mathrm{kHz}$ and a scan rate of $0.5 \mathrm{~Hz}$ using a tip with a radius of $10 \mathrm{~nm}$ and a height of $10-15 \mu \mathrm{m}$. The average surface roughness $\left(\mathrm{R}_{\mathrm{a}}\right)$ was quantified on three different locations of each sample using images of $100 \times 100 \mu \mathrm{m}^{2}$ and presented as average with standard deviation.

\section{Bacteria}

S. aureus ATCC 49230 is a biofilm-producing strain (Li et al., 2008) originally isolated from a patient with osteomyelitis (Smeltzer et al., 1997). In the in vivo studies, in order to verify the identity of the challenge strain after re-isolation, we constructed a green fluorescent $S$. aureus ATCC 49230 strain by introducing plasmid WVW189, essentially as described earlier (Riool et al., 2014). This plasmid carries the $g f p_{u v r}$ gene under control of a constitutive $S$. aureus promoter and a chloramphenicol resistance gene for selection (Rooijakkers et al., 2005). The strain, $S$. aureus ATCC 49230 GFP, was designated $S$. aureus GFP in this paper, for brevity. During growth, the plasmid was 
stably maintained by the $S$. aureus GFP bacteria, even in absence of chloramphenicol. Chloramphenicol $(10 \mu \mathrm{g} /$ $\mathrm{mL}$ ) was, however, always added to cultures of the strain used to prepare inocula, in order to avoid any potential loss of the plasmid. The susceptibility to chlorhexidine and the growth rate in tryptic soy broth (TSB; BD Difco) of $S$. aureus GFP and of the wild type $S$. aureus ATCC 49230 were equal (data not shown). In previous studies we showed that the presence of plasmid WVW189 did not influence the virulence of Staphylococcus epidermidis in mice (Riool et al., 2014).

\section{Surface bactericidal activity assay}

A modified version (Necula et al., 2009) of the Japanese Industrial Standard test for surface microbicidal activity [JIS Z 2801:2000 (Japanese Standards Association, 2000)] was used to evaluate the bactericidal activity of quadruplicate coated titanium disks against $S$. aureus. In short, $S$. aureus was cultured shaking at $37^{\circ} \mathrm{C}$ in TSB with $10 \mu \mathrm{g} / \mathrm{mL}$ chloramphenicol, up to the logarithmic growth phase. Subsequently, the bacteria were diluted with TSB to $10^{7}$ colony forming units $(\mathrm{CFU}) / \mathrm{mL}$, based on the optical density at $620 \mathrm{~nm}\left(\mathrm{OD}_{620}\right)$. UV-sterilised nitrocellulose filter disks (diameter $13 \mathrm{~mm}$ ) were placed on a Colombia sheep blood agar plate and $20 \mu \mathrm{L}$ of the diluted bacterial culture, containing $2 \times 10^{5} \mathrm{CFU}$, were pipetted onto the filters. The medium was absorbed by the agar, while the bacteria were retained on the filter. $20 \mu \mathrm{L}$ of $1 \%$ TSB in $10 \mathrm{mM}$ phosphate buffer were pipetted centrally on the surface of each titanium disk and an inoculated filter disk was carefully placed on top, with the bacteria contacting the coated surface. All disks with bacterial filters were placed individually in Petri dishes and incubated at $37^{\circ} \mathrm{C}$ for $24 \mathrm{~h}$ in a humid atmosphere. After incubation, each disk and the corresponding filter were placed together in $5 \mathrm{~mL}$ of TSB, sonicated for $30 \mathrm{~s}$ in a sonicator water bath (Elma Transsonic T460, $35 \mathrm{kHz}$; Elma Schmidbauer GmbH, Singen, Germany) and vortexed for $1 \mathrm{~min}$ to dislodge adherent bacteria. This procedure does not affect bacterial viability (Boelens et al., 2000a). Per sample, two independent 10 -fold serial dilutions were made in a microtiter plate and duplicate $10 \mu \mathrm{L}$ aliquots of the undiluted suspension and of the dilutions were pipetted onto blood agar plates. The blood agar plates were incubated overnight at $37^{\circ} \mathrm{C}$ and number of colonies was counted the following day.

\section{Mouse experimental biomaterial-associated infection model}

An established subcutaneous biomaterial-associated infection model was used to assess prevention of infection (Boelens et al., 2000c; Broekhuizen et al., 2009; Christensen et al., 1983; Riool et al., 2014). In this model, planktonic bacteria are injected along the implant, as opposed to biofilm treatment models, where bacterial biofilm are pre-grown on the implant surface prior to implantation (Riool et al., 2014). The mouse study was approved by the Animal Ethical Committee of the Academic Medical Center at the University of Amsterdam, The Netherlands. Specific pathogen-free C57BL/6J OlaHsd immune competent female mice (Envigo, Horst, The
Netherlands), 7 to 9 weeks old and weighing 17 to $20 \mathrm{~g}$, were used.

Mice were anaesthetised with $2 \%$ isoflurane (Pharmachemie) in oxygen in a laminar flow cabinet, followed by a subcutaneous injection of buprenorphine (0.05 mg/kg; Temgesic, RB Pharmaceuticals Limited) for pain control, 15 min prior to the surgical procedure. The backs of the mice were shaved and disinfected with $70 \%$ ethanol. On each side, an incision of $0.5 \mathrm{~cm}$ was made, $1 \mathrm{~cm}$ lateral to the spine. Subsequently, the (coated) titanium biomaterials were implanted subcutaneously with minimal tissue damage using a transponder, specifically designed for these implants (Riool et al., 2014). The incisions were closed with a single 0/6-vicryl stitch (Vicryl, Ethicon).

S. aureus GFP was cultured in TSB with $10 \mu \mathrm{g} / \mathrm{mL}$ chloramphenicol to the mid-logarithmic growth phase. The bacteria were washed in $0.9 \% \mathrm{NaCl}$ (saline) and resuspended in saline, based on the $\mathrm{OD}_{620}$, to $4 \times 10^{6}$ [inoculum size was based on previous experience with $S$. aureus in the mouse BAI model (de Breij et al., 2016)] or $4 \times 10^{7} \mathrm{CFU} / \mathrm{mL}$. Immediately following implantation, $25 \mu \mathrm{L}$ of either of the $S$. aureus GFP inoculum suspensions, containing $10^{5}$ or $10^{6} \mathrm{CFU}$, respectively, were injected along the (coated) implants using a repetitive injector (Stepper model 4001-025; Dymax Corporation, Torrington, CT, USA). Groups of 9 mice with 2 implants each were used in the experiments. Mice were housed singly in individually ventilated cages (IVCs) and were provided with sterile food and water ad libitum.

1 or $4 \mathrm{~d}$ after implantation, mice were anaesthetised with $2 \%$ isoflurane in oxygen and buprenorphine was administered for pain control $15 \mathrm{~min}$ before biopsies were taken. Standardised biopsies (diameter $12 \mathrm{~mm}$ ) were taken from the implantation sites as described previously (Boelens et al., 2000a; Riool et al., 2014) and subsequently mice were euthanised by cervical dislocation. Each biopsy included skin, subcutaneous tissue and the implant. The implant was separated from the tissue and both implant and tissue were used for quantitative culture of bacteria. The implants were vortexed briefly in $0.5 \mathrm{~mL}$ of PBS to remove non-adherent bacteria and then sonicated in saline for $5 \mathrm{~min}$ in a water bath sonicator to dislodge adherent bacteria. The tissue samples were homogenised in $0.5 \mathrm{~mL}$ of PBS using 5 zirconia beads ( $2 \mathrm{~mm}$ diameter, BioSpec Products, Bartlesville, OK, USA) and the MagnaLyser System (Roche), with 3 cycles of $30 \mathrm{~s}$ at $7000 \mathrm{rpm}$, with $30 \mathrm{~s}$ cooling on ice between cycles. Like the sonication procedure of the implants, this homogenisation procedure does not affect the viability of staphylococci (Boelens et al., 2000a). The sonicates and homogenates were 10-fold serially diluted and plated on blood agar plates. In addition, the sonicated implants and $50 \mu \mathrm{L}$ of each homogenate were cultured in $5 \mathrm{~mL}$ TSB containing $0.5 \%$ (v/v) Tween-80, shaking at $37{ }^{\circ} \mathrm{C}$ for $48 \mathrm{~h}$. The cultured $S$. aureus GFP bacteria were distinguished from mouse flora by inspection under exposure to UV light in a G:box (Syngene). The number of cultured bacteria was expressed as log CFU per implant or per homogenised biopsy. The lower limit of detection was $10 \mathrm{CFU}$. This value was assigned to samples positive in broth and negative in blood agar plate culture. For statistical analysis and to visualise the data 
on a logarithmic scale, a value of 1 CFU per sample was assigned when no growth had occurred in either culture system.

\section{Histology}

Tissue biopsies were embedded in plastic [methyl methacrylate/butyl methacrylate (MMA/BMA); Merck Schuchart] and $3 \mu \mathrm{m}$ sections were cut from these samples. In each experimental group, 4 biopsies were randomly selected for histological examination and one or two microscopic sections per biopsy were immunohistochemically stained. The sections were deplastified by incubating twice in $100 \%$ acetone for $6 \mathrm{~min}$, washed in demineralised water for $5 \mathrm{~min}$ and incubated in methanol with $0.3 \% \mathrm{H}_{2} \mathrm{O}_{2}$ for $20 \mathrm{~min}$ at RT (room temperature) in the dark, to block endogenous peroxidase activity. The sections were subjected to heatinduced epitope retrieval (HIER) (van der Loos, 2010), performed in a PreTreatment Module (Lab Vision) by incubation in citrate buffer $\mathrm{pH} 6.0$ (TA-250-PM1X, Thermo Fisher Scientific) for $20 \mathrm{~min}$ at $98{ }^{\circ} \mathrm{C}$, rinsed with tap water and incubated with Superblock (AAA999, Klinipath) for $10 \mathrm{~min}$ at RT. Sections were incubated overnight at $4{ }^{\circ} \mathrm{C}$ with rat anti-mouse monoclonal $\mathrm{F} 4 / 80$ (macrophages; MCA497GA, clone: CI:A3-1, Serotec) diluted 1: 1000 in Tris-HCl-buffered saline (TBS; $50 \mathrm{mM}$
Tris, $0.9 \% \mathrm{NaCl}$ ), subsequently with rabbit anti-rat IgG (6130-01, fab2; SBA/ITK) diluted 1: 3000 in TBS with $20 \%$ normal mouse serum for $30 \mathrm{~min}$ at RT, followed by undiluted BrightVision anti-rabbit AP (DPVB-55AP, Immunologic) for $30 \mathrm{~min}$ at RT and finally with Vector Blue (SK-5300, Vector Labs) for $10 \mathrm{~min}$ at RT, with three TBS washes between all incubations. After rinsing with tap water, a HIER-citrate antigen retrieval step of $10 \mathrm{~min}$ at $98{ }^{\circ} \mathrm{C}$ and a Superblock step were performed as described above. Next, sections were incubated with 1: 10000 diluted rabbit anti-S. aureus polyclonal IgG (20920, Abcam) for $1 \mathrm{~h}$ at RT, with undiluted BrightVision anti-rabbit AP for 30 min at RT and with Vector Red (SK-5100, Vector Labs) for $10 \mathrm{~min}$ at RT, again with three TBS washes between all incubations. After another HIER-citrate $\left(10 \mathrm{~min}\right.$ at $\left.98{ }^{\circ} \mathrm{C}\right)$ and Superblock incubation, sections were incubated with 1: 1000 diluted rat anti-mouse Ly-6G-FITC (neutrophils; 553126, BD) in TBS for $2 \mathrm{~h}$ at RT, with 1: 1000 diluted rabbit anti-FITC (4510-7804, Nuclilab) in the presence of $5 \%$ normal mouse serum in TBS for $15 \mathrm{~min}$ at RT, with undiluted BrightVision anti-rabbit IgG-HRP (DPVR110HRP, Immunologic) for $30 \mathrm{~min}$ at RT, and finally stained for $\sim 8$ min with DAB (BS04-110, Immunologic) until they turned yellow/brownish. Sections were then washed with tap water, stained with 10-fold diluted haematoxylin (4085-9002, Klinipath) for $2 \mathrm{~min}$, washed
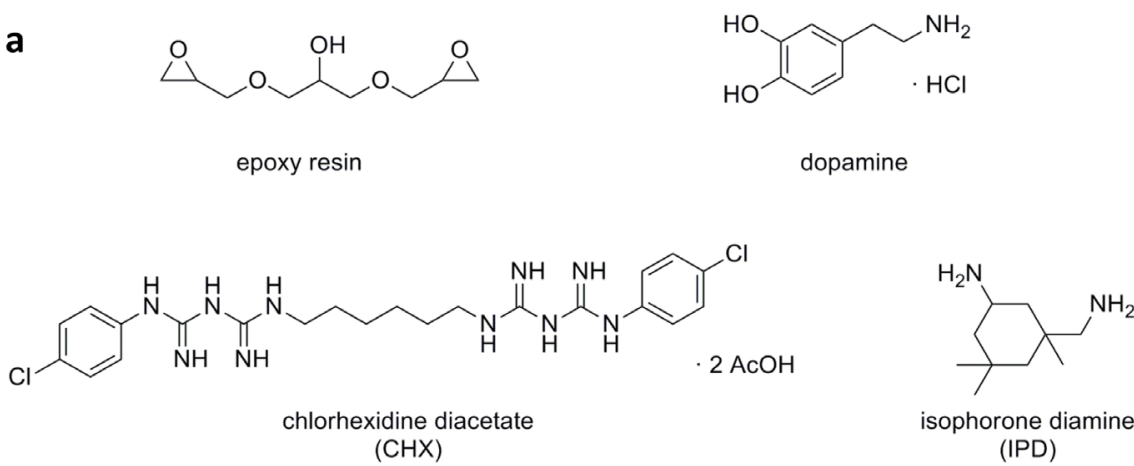

(IPD)

b

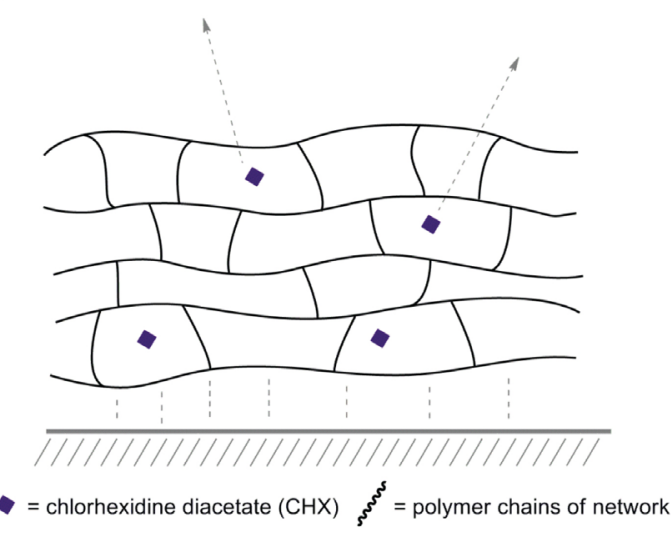

C<smiles>CC(C)N(C)CC(O)CN(C)CC(O)COCC(O)COCC(O)CN(C)CC(O)COCC(O)COCC(O)CN(C)CCc1ccc(O)c(O)c1</smiles>

Fig. 1. Overview of the coating components (a) and architecture (b,c). (a) The coating components: epoxy resin (i.e. the diglycidyl ether of glycerol), dopamine, chlorhexidine diacetate (CHX) and isophorone diamine (IPD). (b) Schematic representation of the coating architecture, including chlorhexidine diacetate (CHX; diamonds) release from the epoxy-based coating on a substrate (////).(c) Representation of a (possible) crosslink within the network. 
with tap water and dried on a heat block at $50{ }^{\circ} \mathrm{C}$. A drop of VectaMount (H-5000, Vector Labs) was applied and the sections were covered with a coverslip.

Between 2 and 5 multispectral imaging data sets of the immunohistochemically stained sections were acquired at 420 to $720 \mathrm{~nm}$ with intervals of $20 \mathrm{~nm}$, using the Nuance Imaging System (PerkinElmer/Caliper Life Science). The data sets were spectrally unmixed to identify the different cell types (macrophages, neutrophils and bacteria). In the negative controls without primary antibodies no staining was observed.

\section{Statistical analysis}

All statistical analyses were performed in Graphpad Prism. For CFU counts, two-sample comparisons were made using a two-tailed Mann-Whitney rank sum test. The significance of differences between the frequencies of categorical variables was determined using Fisher's exact test. For all tests, $p \leq 0.05$ was considered significant.

\section{Results}

\section{Coating synthesis and characterisation}

A procedure for the preparation of the coating formulation was established utilising the diglycidyl ether of glycerol as the epoxy resin, IPD for curing and dopamine to optimise the adhesion to titanium (Fig. 1a). Ensuring a close to equimolar ratio of $\mathrm{NH} / \mathrm{epoxy}$ in the coating formulations (Table 1) resulted in a highly cross-linked network (Fig. 1c) when the procedure was applied to aluminium sheets and Q-panels as well as to titanium disks. The coatings showed excellent resistance to rubbing, with no visible damage after 200 double-rubs (classification: 5). Moreover,

\section{non-coated}
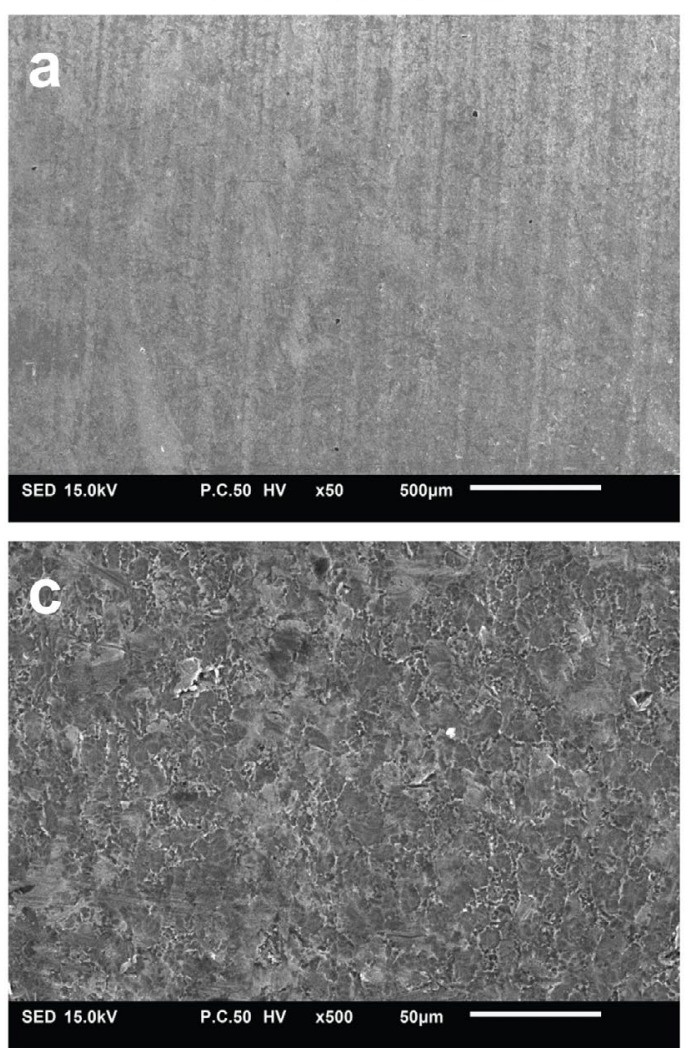

\section{e}

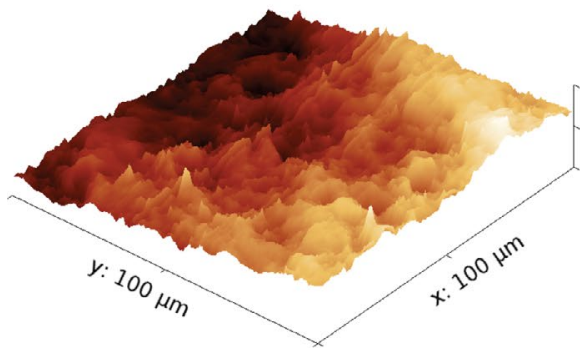

$4.8 \mu \mathrm{m}$ $0.0 \mu \mathrm{m}$
$\mathrm{CHX}_{10}$-coated
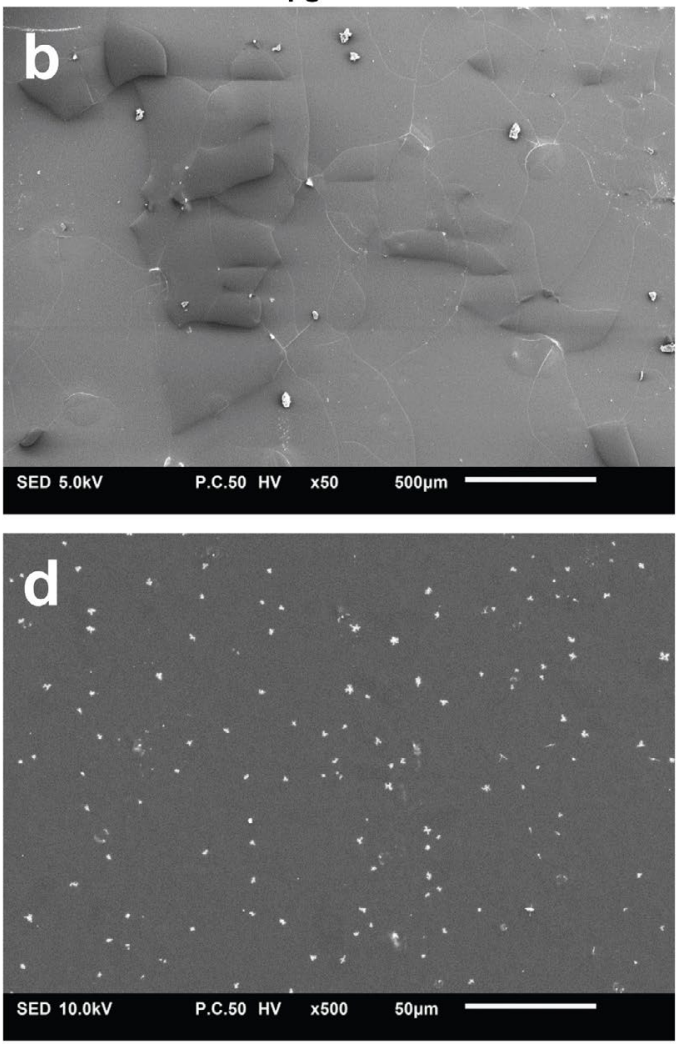

\section{f}

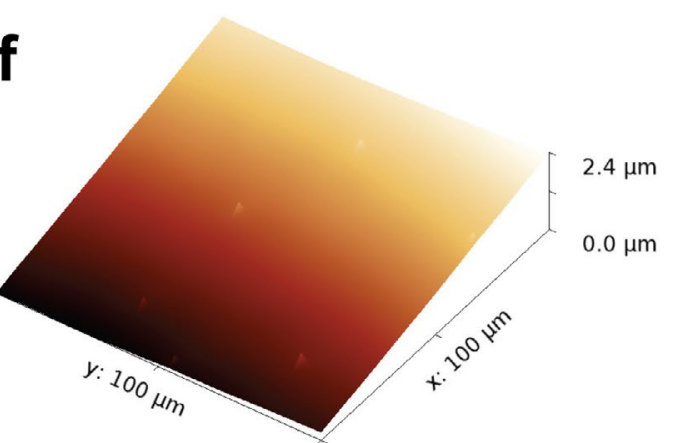

Fig. 2. Surface morphology of non-coated (left panels) and $\mathrm{CHX}_{10}$-coated titanium implants (right panels) shown by SEM recordings at $50 \times(\mathbf{a}, \mathbf{b})$ and $500 \times$ magnification $(\mathbf{c}, \mathbf{d})$ and $3 \mathrm{D}$ morphology by AFM analysis (e,f). 


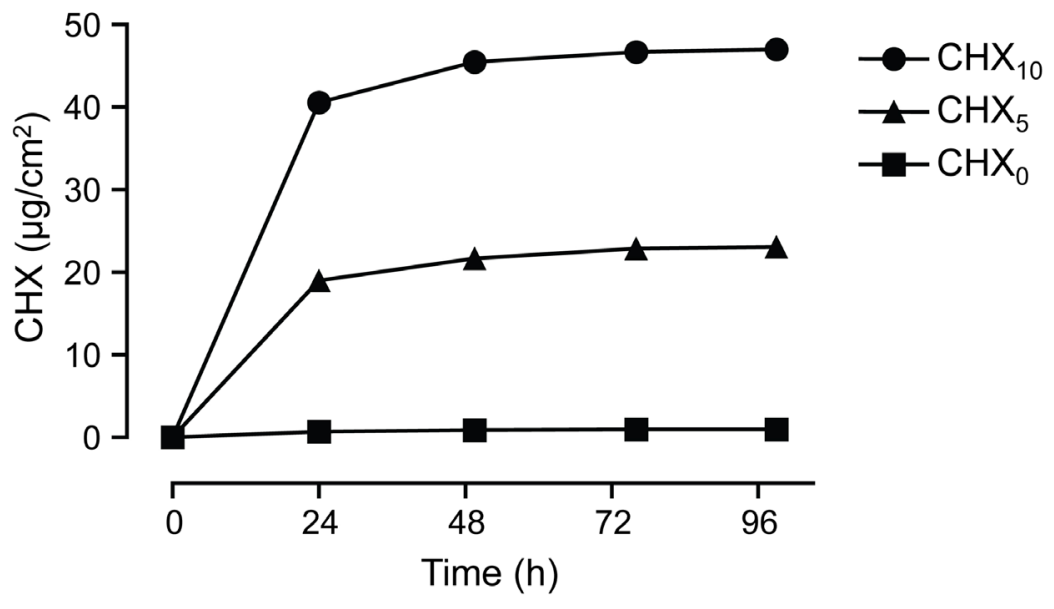

Fig. 3. Cumulative release of chlorhexidine $\left(\mu \mathrm{g} / \mathrm{cm}^{2}\right)$ from aluminium sheets coated with $\mathrm{CHX}_{0}$ (no CHX; squares), $\mathrm{CHX}_{5}$ (5 wt \% CHX; triangle) or $\mathrm{CHX}_{10}(10$ wt \% CHX; circles) over time. Results of one representative experiment.

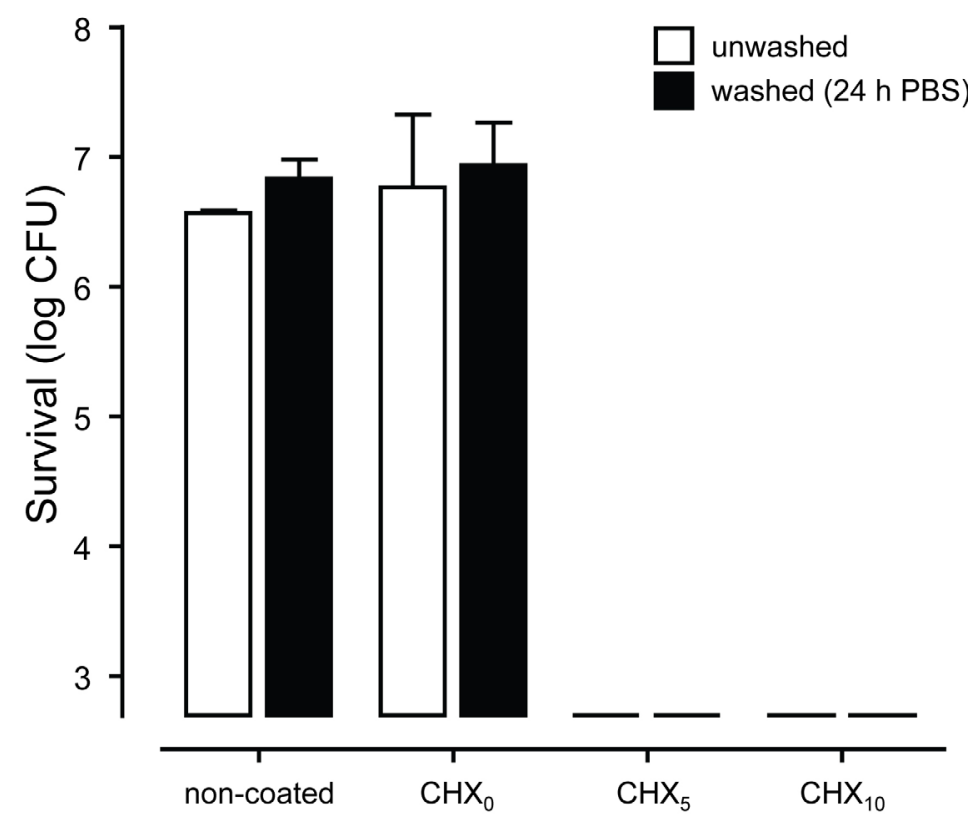

Fig. 4. Surface bactericidal activity of chlorhexidine-releasing epoxy-based coating on titanium disks against $2 \times 10^{5} \mathrm{CFU}$ of $S$. aureus. The survival of the bacteria $24 \mathrm{~h}$ after application on unwashed (white bars) and washed (24 h in PBS; black bars) disks is shown. Non-coated, titanium disks without coating; $\mathrm{CHX}_{0}$, titanium disks with coating not containing chlorhexidine; $\mathrm{CHX}_{5}$ and $\mathrm{CHX}_{10}$, titanium disks with coating containing 5 or $10 \mathrm{wt} \%$ chlorhexidine, respectively. The detection limit was log $2.7 \mathrm{CFU}$ of $S$. aureus.

no visual damage was observed upon tape stripping (classification: 5), proving a good adhesion of the coating to the substrate. The mechanical properties of the coatings did not change when the coated substrates had been incubated in PBS at $37^{\circ} \mathrm{C}$ for $48 \mathrm{~h}$ prior to the mechanical testing. Next, we prepared the same coating formulations with chlorhexidine diacetate added at approximately 5 and $10 \mathrm{wt} \%$ of the total solid content or without this agent (Fig. 1b). Separate batches of coating formulations were prepared for the in vitro studies $\left(\mathrm{CHX}_{0}, \mathrm{CHX}_{5}\right.$ and $\left.\mathrm{CHX}{ }_{10}\right)$ and for the in vivo studies $\left(\mathrm{CHX}_{0}\right.$ and $\left.\mathrm{CHX}_{10}\right)$ (Table 1). No differences were observed between the mechanical properties of the separate batches of identical formulations.

The SEM analyses of the non-coated surfaces showed a rough topography with visible grooves (Fig. 2a) and enhanced local roughness (Fig. 2c), which was also affirmed by the 3D morphology as assessed by AFM, with an estimated average surface roughness $\left(R_{a}\right)$ of $861.9 \pm 27 \mathrm{~nm}$ (Fig. 2e). In contrast, the $\mathrm{CHX}_{10}$-coated samples showed a smooth (Fig. 2f; $R_{a}$ of $530.5 \pm 15 \mathrm{~nm}$ ), compact and non-porous layer completely covering the original titanium topography (Fig. 2b,d). In addition, white structures protruding from the surface were visible on the coated samples, both in SEM (Fig. 2b,d) and AFM (Fig. 2f). The nature of these protrusions remains elusive.

\section{In vitro chlorhexidine release}

The release curves showed that the total amount of released chlorhexidine could be adjusted by changing the concentration of chlorhexidine in the formulation, i.e. 5 versus $10 \mathrm{wt} \%$ chlorhexidine $\left(\mathrm{CHX}_{5}\right.$ and $\mathrm{CHX}_{10}$ in Fig. 3). Chlorhexidine was released from the $\mathrm{CHX}_{5}$ - and $\mathrm{CHX}_{10}{ }^{-}$ coated aluminium sheets in a burst-release fashion with $>80 \%$ of the release, 19 and $41 \mu \mathrm{g} / \mathrm{cm}^{2}$ chlorhexidine, respectively, occurring in the first $24 \mathrm{~h}$. After $4 \mathrm{~d}, 23$ and $47 \mu \mathrm{g} / \mathrm{cm}^{2}$ chlorhexidine were released from the $\mathrm{CHX}_{5}$ - and $\mathrm{CHX}_{10}$-coated sheets, respectively.

\section{In vitro surface bactericidal activity}

The $\mathrm{CHX}_{5}$ and $\mathrm{CHX}_{10}$ coatings applied on titanium disks completely killed the $S$. aureus inoculum after $24 \mathrm{~h}$ of incubation (Fig. 4). After washing with PBS for $24 \mathrm{~h}$, both the $\mathrm{CHX}_{5}$ and $\mathrm{CHX}_{10}$ coatings remained fully bactericidal. The coating without chlorhexidine $\left(\mathrm{CHX}_{0}\right)$ did not reduce 
survival of $S$. aureus, showing that the bactericidal activity of the $\mathrm{CHX}_{5}$ and $\mathrm{CHX}_{10}$ coatings was due to the release of chlorhexidine.

\section{In vivo antibacterial activity of $\mathrm{CHX}_{10}$-coated titanium implants in mouse experimental BAI}

In a first experiment, mice were either sham-operated or they received non-coated, $\mathrm{CHX}_{0}$ - or $\mathrm{CHX}_{10}$-coated titanium subcutaneous implants. An S. aureus GFP inoculum of $10^{5} \mathrm{CFU}$ was subsequently injected at the site of sham surgery in the sham-operated mice or along the implants in the other mice. A potentially protective effect of the $\mathrm{CHX}_{10}$ coating against colonisation of the implants could not be assessed, since the level of implant colonisation in the animals receiving non-coated or $\mathrm{CHX}_{0}$-coated implants appeared to be unexpectedly low (Fig. 5). The level of tissue colonisation did however allow evaluation. $1 \mathrm{~d}$ after challenge, tissues from sham-operated mice and from mice receiving non-coated implants did not differ in frequency of culture positive tissues nor in number of CFU cultured from these tissues. In the group of mice with $\mathrm{CHX}_{10}$-coated implants, the frequency of culturepositive tissues was lower than in the mice with non-coated implants $(p=0.0016)$ and the number of CFU retrieved was lower than from tissues of mice with $\mathrm{CHX}_{0}$-coated $(p=0.029)$ or non-coated implants $(p=0.0022)$ (Fig. 5).
No apparent macroscopic signs of toxicity or inflammation were observed in any of the mice.

In order to allow evaluation of an effect of the $\mathrm{CHX}_{10}$ coating on implant colonisation, we repeated the experiment with an $S$. aureus GFP inoculum of $10^{6} \mathrm{CFU}$ with expected higher levels of in vivo colonisation of non-coated implants. We used the coating with the greatest chlorhexidine content $\left(\mathrm{CHX}_{10}\right)$ and non-coated implants for comparison. With this increased inoculum size, both the implant surfaces and the peri-implant tissues were strongly colonised in the group of mice with non-coated implants (Fig. 6). In this group, $1 \mathrm{~d}$ after challenge, $100 \%$ of the tissues and $89 \%$ of the implants were culture positive. Similarly, at day 4, $83 \%$ of the tissues and $28 \%$ of the implants were culture positive and number of CFU retrieved from the implants and the surrounding tissue was larger with this increased inoculum size than with an inoculum of $10^{5} \mathrm{CFU}$ used in the previous experiment (compare Fig. 6 to Fig. 5).

$1 \mathrm{~d}$ after challenge, the $\mathrm{CHX}_{10}$ coating significantly reduced the number of culture-positive implants $(p<0.001)$ as well as the number of CFU in the tissue $(p=0.0015)$ and on the implants $(p<0.001) .4 \mathrm{~d}$ after challenge, the group with $\mathrm{CHX}_{10}$-coated implants had significantly smaller number of culture-positive tissues $(p=0.0153)$ and culture-positive implants $(p=0.0455)$ than mice with non-coated implants. $1 \mathrm{~d}$ after challenge, only 4 of the

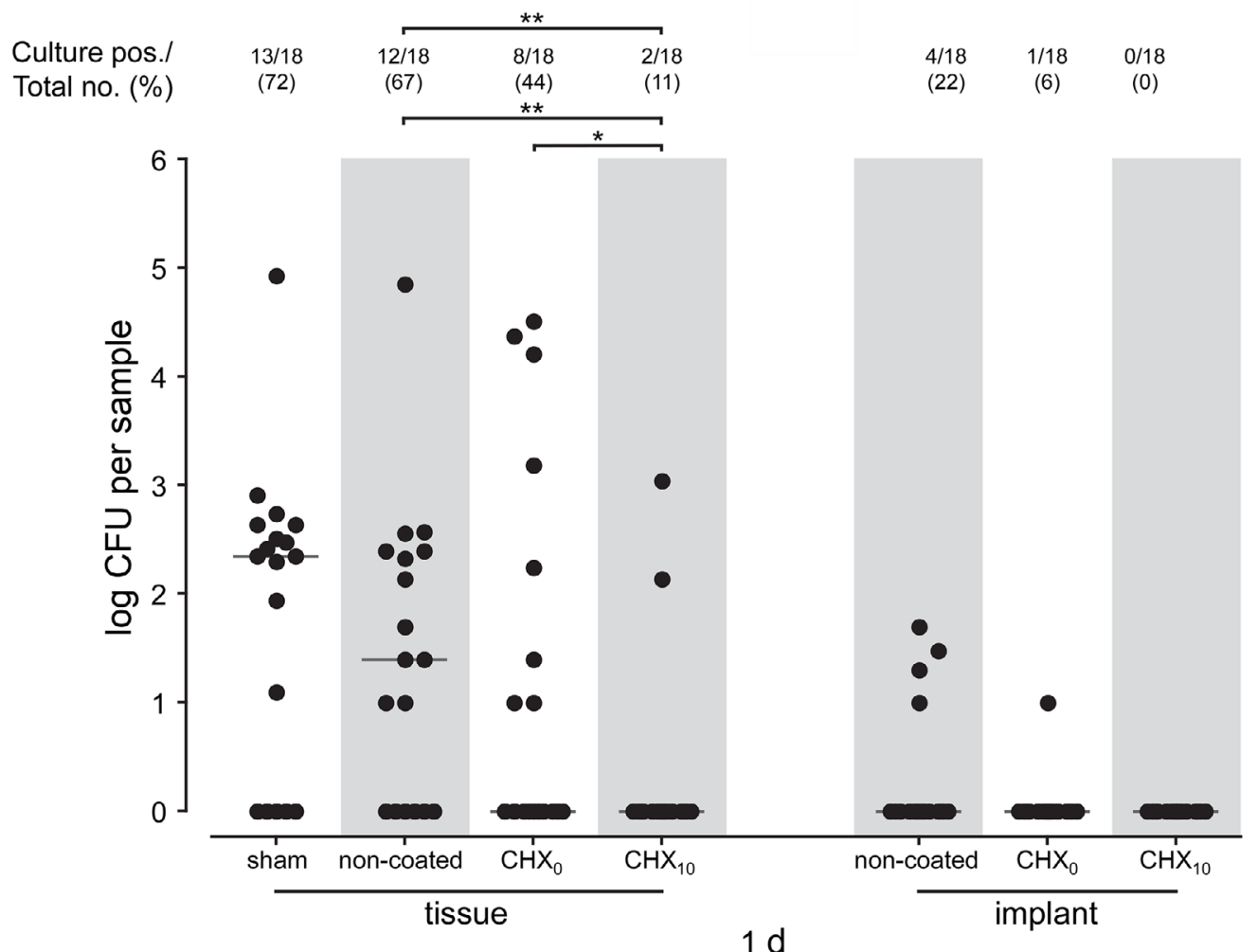

Fig. 5. Bactericidal activity of chlorhexidine-releasing epoxy-based coatings applied on titanium implants against $1 \times 10^{5} \mathrm{CFU}$ of $S$. aureus GFP in mouse experimental biomaterial-associated infection $1 \mathrm{~d}$ after implantation. Sham, surgery but no implant; non-coated, titanium implant without coating; $\mathrm{CHX}_{0}$, titanium implant with coating not containing chlorhexidine; $\mathrm{CHX}_{10}$, titanium implant with coating containing $10 \mathrm{wt} \%$ chlorhexidine. Results are expressed as the frequencies and percentages of culture-positive samples and as the log of the numbers of CFU retrieved. The horizontal line represents the median log CFU. Frequencies of culture-positive samples and log numbers of CFU were analysed by Fisher's exact and Mann-Whitney tests, respectively. ${ }^{*} p \leq 0.05$ and ${ }^{* *} p \leq 0.01$. 
$\mathrm{CHX}_{10}$-coated implants were culture positive, yielding a small number of CFUs and the surfaces of all $\mathrm{CHX}_{10^{-}}$ coated implants were culture negative $4 \mathrm{~d}$ after challenge. No apparent macroscopic signs of toxicity or inflammation were observed in the peri-implant tissue of any of the mice. Thus, the release of chlorhexidine proved to be effective to prevent $S$. aureus colonisation of the implant and the surrounding tissue in vivo with no visible adverse effects.

\section{Histology}

To assess the influence of the coatings on the local immune response, we simultaneously stained polymorphonuclear neutrophils (PMNs), macrophages and bacteria in single histological slides of tissue sections and visualised the cells using multispectral imaging. $1 \mathrm{~d}$ after challenge, a strong infiltration of PMNs as well as of macrophages around the non-coated titanium samples was observed (Fig. 7a). At this early time point, clearly less PMNs were present around the $\mathrm{CHX}_{10}$-coated implants. $4 \mathrm{~d}$ after challenge, the foreign body response had progressed from neutrophil to macrophage (F4/80 positive cells) predominance, around both the non-coated and the $\mathrm{CHX}_{10}$-coated titanium implants (Fig. 7c,d). So, in line with our macroscopic observations, there were no microscopic signs of in vivo adverse effects, such as excessively increased or protracted neutrophil-dominated inflammatory responses nor necrosis, which might have been caused by the coating components or the chlorhexidine released.

$1 \mathrm{~d}$ after challenge, many bacteria were observed in the tissue around the non-coated implant (Fig. 7a) and only few bacteria around the $\mathrm{CHX}_{10}$-coated implant (Fig. 7b), which was in accordance with the quantitative culture results (Fig. 6). The bacteria were mainly co-localised with the PMNs. Although the number of culture-positive tissues around $\mathrm{CHX}_{10}$-coated implants $4 \mathrm{~d}$ after challenge was smaller compared to the tissues around non-coated implants, the number of CFUs retrieved was similar. This was also true for the number of bacteria observed by histology in the tissue surrounding the non-coated (Fig. 7c) and $\mathrm{CHX}_{10}$ coated implants (Fig. 7d). $4 \mathrm{~d}$ after challenge the bacteria were mainly co-localised with macrophages.

\section{Discussion}

We have developed an epoxy-based mechanically stable coating for titanium implants providing a predetermined release of chlorhexidine to prevent biomaterial-associated infection (BAI). The epoxy-based coatings containing 5 or $10 \mathrm{wt} \%$ chlorhexidine, $\mathrm{CHX}_{5}$ and $\mathrm{CHX}_{10}$, displayed an initial burst release in the first $24 \mathrm{~h}$ and the residual release occurring within $4 \mathrm{~d}$. Additional in vitro studies showed that

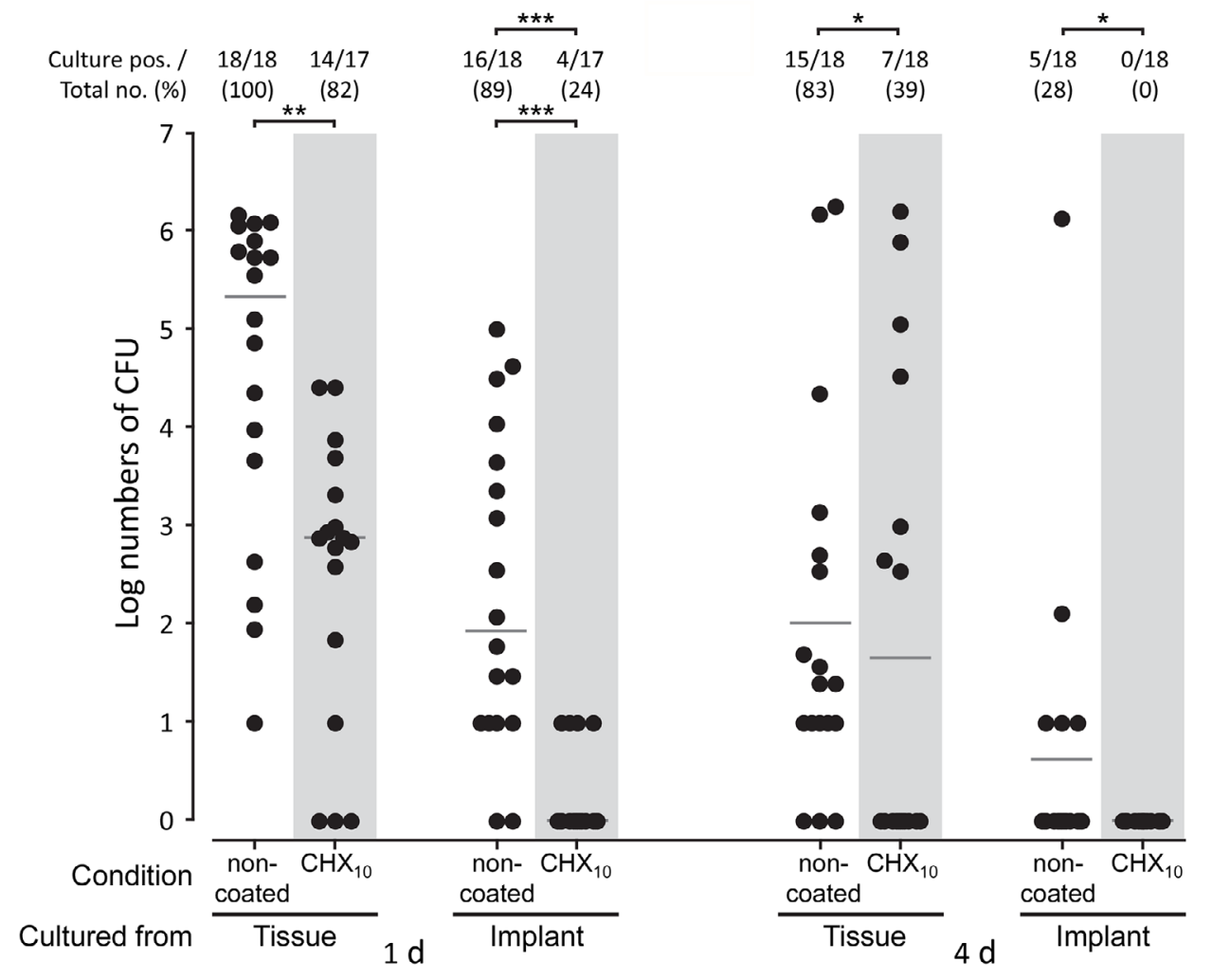

Fig. 6. Bactericidal activity of chlorhexidine-releasing epoxy-based coating on titanium against $1 \times 10^{6} \mathrm{CFU} S$. aureus GFP in mouse experimental biomaterial-associated infection $1 \mathrm{~d}$ (left) and $4 \mathrm{~d}$ (right) after implantation. Noncoated, titanium implant without coating; $\mathrm{CHX}_{10}$, titanium implant with coating containing $10 \mathrm{wt} \%$ chlorhexidine. Results are expressed as the frequencies and percentages of culture-positive samples and as the log of the numbers of CFU retrieved. The horizontal line represents the median $\log$ CFU. Frequencies of culture-positive samples and $\log$ numbers of CFU were analysed by Fisher's exact and Mann-Whitney tests, respectively. ${ }^{*} p \leq 0.05,{ }^{* *} p \leq 0.01$ and $* * * p \leq 0.001$. 

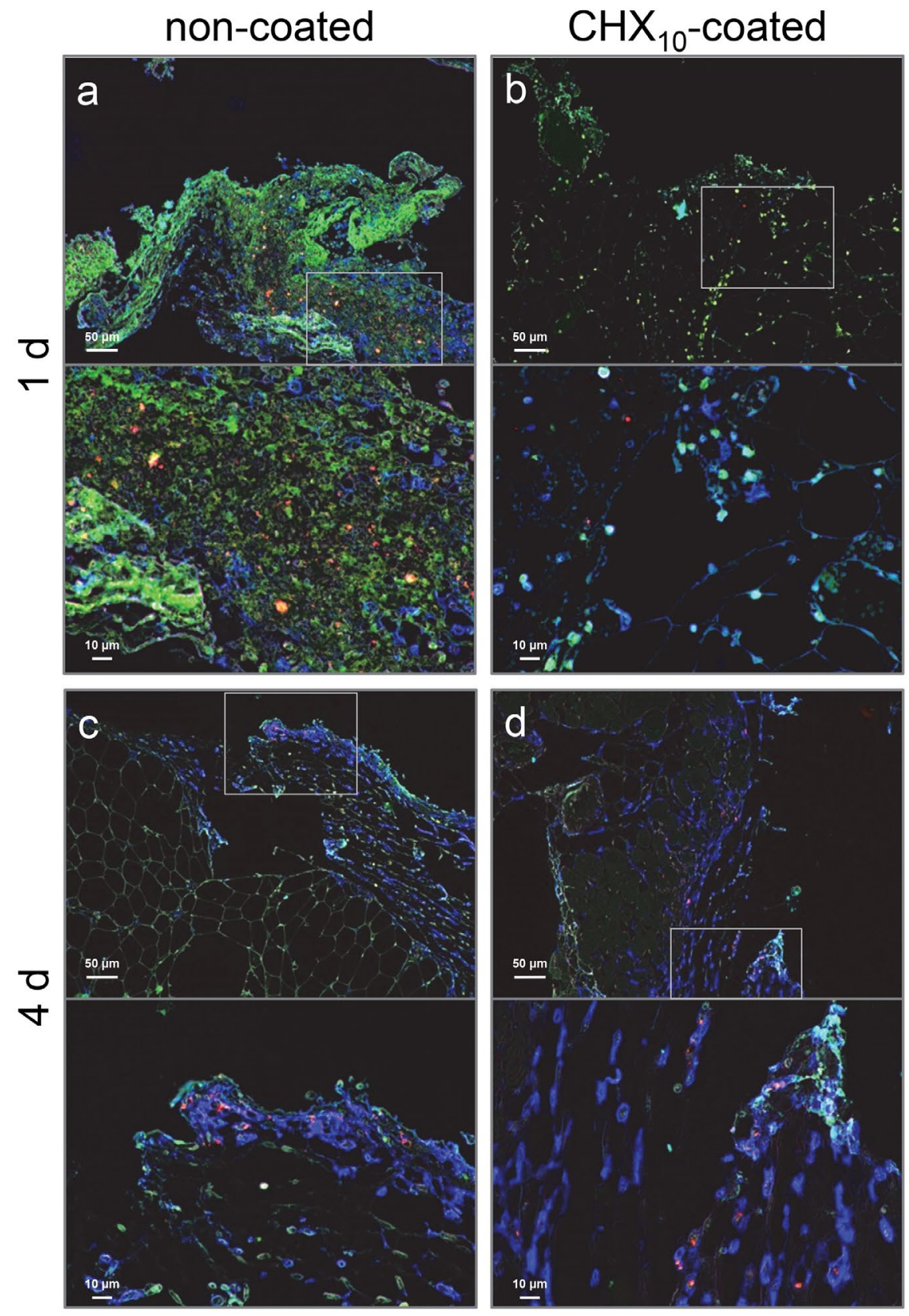

Fig. 7. Histological sections of biopsies of mice with non-coated titanium implants (non-coated (a,c) or with $\mathrm{CHX}_{10}$-coated implants $(\mathbf{b}, \mathbf{d})$, challenged with $1 \times 10^{6} \mathrm{CFU}$ of $S$. aureus GFP and sacrificed after $1 \mathrm{~d}(\mathbf{a}, \mathbf{b})$ or $4 \mathrm{~d}$ (c,d). High magnification images, recorded from boxed area, are shown below the respective images. Macrophages immunostained with F4/80, neutrophils with Ly-6 and bacteria with anti-S. aureus antibodies are shown in multispectral images as blue, green and red, respectively. Co-localisation of macrophages and bacteria are shown in pink, co-localisation of macrophages and neutrophils in light-blue and co-localisation of bacteria and neutrophils in yellow. The images are representative for sections from different levels of the biopsies examined.

the coating completely eradicated the $S$. aureus inoculum even after washing for $24 \mathrm{~h}$ in PBS. The $\mathrm{CHX}_{10}$ coating prevented mouse subcutaneous biomaterial-associated $S$. aureus infection and did not show macroscopic nor microscopic signs of adverse effects.

Coatings and materials derived from epoxy resins have found widespread use in numerous applications. Because of their good adhesion properties and excellent mechanical stability, epoxy-based coatings are highly suited for metallic orthopaedic implants, which are often inserted under mechanical stress. These coatings are particularly suited for non-cemented implants, which in contrast to cemented implants cannot be protected by e.g. antibiotic releasing bone cement (Lynch et al., 1987; Nijhof et al., 2000) or other antimicrobial approaches, such as the use of bioactive glass (Drago et al., 2013; Romano et al., 2014), and are more prone to recurrent infection (Dale et al., 2009; Neut et al., 2015).

Perhaps the most well-known epoxy resin, imparting good mechanical properties to its derived coatings, is the diglycidyl ether of bisphenol-A (DGEBA) (Garcia et al., 2009). Indeed, cured networks of DGEBA and 
isophorone diamine (IPD) for biomedical applications showed respectable mechanical properties and good biocompatibility in vitro (Garcia et al., 2009). However, bisphenol A derivatives are under continuous debate for their safety (Testai et al., 2016). Therefore, we selected the diglycidyl ether glycerol as the epoxy resin, to be cured with IPD, a system shown to be haemocompatible (Garcia et al., 2016) and not toxic in a rabbit bone implant model (Odekerken, 2015). Ensuring a nearly stoichiometric ratio of NH to epoxy groups resulted in a strongly crosslinked network. To further enhance adhesion of the coating to the titanium, dopamine was added to the formulation. The coating did not show any damage after extensive testing in the double rub as well as tape adhesion assays, illustrating its excellent mechanical properties. The coating therefore is a promising candidate for application to titanium implants in orthopaedics and dentistry.

Although antibiotic releasing coatings are widely used for different medical applications, e.g. in sutures and central venous and urinary tract catheters, antibiotic release coatings for orthopaedic devices remain mainly experimental. A study in rabbits with titanium fixation plates coated with poly- ${ }_{\mathrm{L}}$-lactide (PLLA), containing a combination of rifampicin and fusidic acid, placed on the tibia, showed a significant reduction in $S$. aureus infection after 28 d (Kälicke et al., 2006). Direct application of rifampicin and minocycline on titanium significantly reduced $S$. aureus colonisation of femoral medullary nails and device-related osteomyelitis in rabbits after 1 week (Darouiche, 2007). In a rabbit tibia S. aureus infection model, the application of tobramycin to hydroxyapatitecoated titanium implants reduced infection rates and improved osseointegration after $28 \mathrm{~d}$ (Moojen et al., 2009). In another rabbit study, the combination of hydroxyapatite with gentamicin showed significant reduction in S. aureus infection rates, good biocompatibility and bone integration as observed with pure hydroxyapatite (Alt et al., 2011). A gentamicin-loaded biodegradable poly $\left({ }_{D},{ }_{L}-\right.$ lactide $)$ (PDLLA) coating on titanium Kirschner wires showed a significant reduction in implant-related infection after 6 weeks of implantation in a rat tibia infection model (Lucke et al., 2003). A recent prospective study of the first commercially available antibiotic-releasing intramedullary tibia nail, with a coating of PDLLA containing gentamicin, has shown promising results, with no deep surgical wound infections recorded within the first six months after implantation of the coated nails (Fuchs et al., 2011). However, antibiotic-releasing coatings have two major disadvantages. Due to the worldwide rapid increase in antibiotic resistance, there is a risk that a patient will have an infection with a bacterium, which is resistant to the released antibiotic. Conversely, due to the local release, graded concentrations of antibiotic will be present near the implant, increasing the risk of selection of resistant bacteria and thus contributing to resistance development and ensuing implant infection.

In order to avoid antibiotics, we sought to use an antiseptic as the antimicrobial agent for our coating. One of the most frequently used antiseptics is chlorhexidine, with a broad spectrum of activity against Gram-positive and Gram-negative bacteria and yeasts, and with acceptable tolerability and a good safety record (McDonnell and Russell, 1999). Chlorhexidine has been approved by the American Food and Drug Administration (FDA) for application to intracorporally used medical devices, such as surgical meshes (Choe et al., 2000; Pérez-Köhler et al., 2015) and intravenous catheters (Maki, 1997) and has a history of successful clinical (Karpanen et al., 2016) and experimental use in preventing biomaterial-associated and other infections (Darouiche et al., 2008; Sjollema et al., 2014). Chlorhexidine combined with chloroxylenol in a dip-coating on rabbit tibia intramedullary nails prevented experimental S. aureus osteomyelitis (Darouiche et al., 1998a; Darouiche et al., 1998b).

Chlorhexidine is an important agent in the prevention of the spread of antibiotic resistant organisms and hospital-acquired infections (Johnson et al., 2015). The effectiveness and widespread use of chlorhexidine has led to some concerns regarding the emergence of bacterial resistance (Edmiston et al., 2013; Horner et al., 2012), including MRSA resistance (Johnson et al., 2015). However, reported levels of susceptibility of the bacterial isolates are still several orders of magnitude below the clinically applied dosages (Horner et al., 2012).

We tailored our coatings to release most of the chlorhexidine within the first $24 \mathrm{~h}$. As proof of concept for prevention of infection, we studied efficacy in our mouse subcutaneous implant infection model. The $\mathrm{CHX}_{10}$ coating proved to be highly efficacious in preventing $S$. aureus infection and did not cause any signs of adverse effects. Interestingly, $1 \mathrm{~d}$ post challenge only few bacteria were observed in histology and there was only a relatively low level of neutrophil influx in the tissue surrounding the $\mathrm{CHX}_{10}$-coated implants. Likely, this small influx is due to the efficacy of the coating to kill $S$. aureus rapidly, thereby reducing e.g. local complement activation and consequent neutrophil attraction.

Studies in a rabbit tibia intramedullary nail infection model, with titanium implants with the same epoxybased chlorhexidine-releasing coatings as the one used in our study, showed no signs of local nor of systemic toxicity during the 6 week experiment (Odekerken, 2015). Moreover, significantly greater bone apposition on the implant surface of both the $\mathrm{CHX}_{0}(98.8 \%$ coverage $)$ and $\mathrm{CHX}_{10}(81.3 \%$ coverage) than on non-coated titanium nails $(71.5 \%$ coverage) was observed after 6 weeks. However, in contrast to our mouse results, no protection against $S$. aureus infection was observed. This may have been due to the prolonged time period of the rabbit experiments. In the first post-operative week, the rabbits showed reduced ${ }^{18} \mathrm{~F}-\mathrm{FDG}$ tracer uptake suggesting reduced levels of inflammation. This might indicate that a partial suppression of the $S$. aureus infection might have occurred in the first days of the experiment. Apparently, the chlorhexidine reservoir and its release profiles would need to be optimised for the rabbit model, which certainly is possible with this coating technology.

Bacteria colonising the surface of a biomaterial not only are a focus of a localised biofilm infection, but can also be the source of tissue colonisation (Riool et al., 2014). Conversely, bacteria residing in the tissue can be a cause of infection after re-implantation, in experimental infection 
(Engelsman et al., 2010) as well as in patients. Tissueresiding bacteria can be hard to eradicate by antibiotic treatment (Broekhuizen et al., 2008b; Nejadnik et al., 2008) and may necessitate a prolonged regimen of systemic and local antibiotic treatment prior to re-implantation in patients (Zimmerli et al., 2004). Thus, prevention of bacterial colonisation of tissue surrounding implants is of vital importance. In our study, large numbers of bacteria were cultured from the tissues around the non-coated implants. Particularly, $4 \mathrm{~d}$ after challenge, these bacteria were co-localised with macrophages, suggesting that the macrophages were not effectively killing the bacteria. This phenomenon has been observed in many earlier studies (Boelens et al., 2000a; Boelens et al., 2000b; Broekhuizen et al., 2010). However, from the tissue around the $\mathrm{CHX}_{10}$ coated implants, only few bacteria were cultured and few bacteria were seen by histology. Apparently, the rapid initial release of chlorhexidine killed the vast majority of the infecting bacteria, preventing formation of a biofilm on the implant surface as well as colonisation of the tissue, thus protecting both these sites against infection.

\section{Conclusions}

Taken together, our mechanically stable chlorhexidinereleasing epoxy-based coating on titanium holds promise for further development towards clinical application. Because of its mechanical stability, it is suited for all types of bone implants, including but not limited to non-cemented orthopaedic implants and possibly dental implants as well. Our coating provides a good alternative for coatings releasing conventional antibiotics and therefore has the potential not only of preventing implant infection but also contributing to reduction of antibiotic resistance development.

\section{Acknowledgements}

Niels Kamp (Animal Research Institute AMC (ARIA), Amsterdam, The Netherlands) is much acknowledged for his support in the animal experiments. Prof. Dr Ir. Henk J. Busscher and Dr Jelmer Sjollema (University Medical Center Groningen and University of Groningen, Groningen, The Netherlands) are thanked for their valuable discussions. This research forms part of the Project P4.01 NANTICO of the research program of the BioMedical Materials institute, co-funded by the Dutch Ministry of Economic Affairs.

\section{References}

Alt V, Bitschnau A, Böhner F, Heerich KE, Magesin E, Sewing A, Pavlidis T, Szalay G, Heiss C, Thormann U, Hartmann S, Pabst W, Wenisch S, Schnettler R (2011) Effects of gentamicin and gentamicin-RGD coatings on bone ingrowth and biocompatibility of cementless joint prostheses: an experimental study in rabbits. Acta Biomater 7: 1274-1280.

Anderson JM, Marchant RE (2000) Biomaterials: factors favoring colonization and infection, p 89-109. In Waldvogel F, Bisno A (ed), Infections associated with indwelling medical devices, third edition. ASM Press, Washington, DC. DOI:10.1128/9781555818067.ch5

Berruet R, Vinard E, Calle A, Tighzert HL, Chabert B, Magloire H, Eloy R (1987) Mechanical properties and biocompatibility of two polyepoxy matrices: DGEBADDM and DGEBA-IPD. Biomaterials 8: 162-171.

Boelens JJ, Dankert J, Murk JL, Weening JJ, van der Poll T, Dingemans KP, Koole L, Laman JD, Zaat SAJ (2000a) Biomaterial-associated persistence of Staphylococcus epidermidis in pericatheter macrophages. J Infect Dis 181: 1337-1349.

Boelens JJ, van der Poll T, Dankert J, Zaat SAJ (2000b) Interferon- $\gamma$ protects against biomaterial-associated Staphylococcus epidermidis infection in mice. J Infect Dis 181: 1167-1171.

Boelens JJ, Zaat SAJ, Meeldijk J, Dankert J (2000c) Subcutaneous abscess formation around catheters induced by viable and nonviable Staphylococcus epidermidis as well as by small amounts of bacterial cell wall components. J Biomed Mater Res 50: 546-556.

Broekhuizen CAN, Schultz MJ, van der Wal AC, Boszhard L, de Boer L, Vandenbroucke-Grauls CMJE, Zaat SAJ (2008a) Tissue around catheters is a niche for bacteria associated with medical device infection. Crit Care Med 36: 2395-2402.

Broekhuizen CAN, Sta M, Vandenbroucke-Grauls CMJE, Zaat SAJ (2010) Microscopic detection of viable Staphylococcus epidermidis in peri-implant tissue in experimental biomaterial-associated infection, identified by bromodeoxyuridine incorporation. Infect Immun $\mathbf{7 8}$ : 954-962.

Broekhuizen CAN, de Boer L, Schipper K, Jones CD, Quadir S, Feldman RG, Vandenbroucke-Grauls CMJE, Zaat SAJ (2009) The influence of antibodies on Staphylococcus epidermidis adherence to polyvinylpyrrolidone-coated silicone elastomer in experimental biomaterial-associated infection in mice. Biomaterials 30: 6444-6450.

Broekhuizen CAN, de Boer L, Schipper K, Jones CD, Quadir S, Vandenbroucke-Grauls CMJE, Zaat SAJ (2008b) Staphylococcus epidermidis is cleared from biomaterial implants but persists in peri-implant tissue in mice despite rifampicin/vancomycin treatment. J Biomed Mater Res Part A 85: 498-505.

Brooks BD, Brooks AE, Grainger DW (2013) Antimicrobial medical devices in preclinical development and clinical use. Biomater Assoc Infect, Springer Link, New York 307-354.

Busscher HJ, van der Mei HC, Subbiahdoss G, Jutte PC, van den Dungen JJ a M, Zaat SAJ, Schultz MJ, Grainger DW (2012) Biomaterial-associated infection: locating the finish line in the race for the surface. Sci Transl Med 4: 153 rv10.

Choe JM, Ogan K, Bennett S (2000) Antibacterial mesh sling: a prospective outcome analysis. Urology 55: 515-520. 
Christensen GD, Simpson W a, Bisno a L, Beachey EH (1983) Experimental foreign body infections in mice challenged with slime-producing Staphylococcus epidermidis. Infect Immun 40: 407-410.

Costerton JW, Stewart PS, Greenberg EP (1999) Bacterial biofilms: a common cause of persistent infections. Science 284: 1318-1322.

Dale H, Hallan G, Espehaug B, Havelin LI, Engesæter LB (2009) Increasing risk of revision due to deep infection after hip arthroplasty. Acta Orthop 80: 639-645.

Darouiche RO (2007) In vivo efficacy of antimicrobialcoated devices. J Bone Joint Surg Am 89: 792.

Darouiche RO, Mansouri MD, Gawande P V, Madhyastha S (2008) Efficacy of combination of chlorhexidine and protamine sulphate against deviceassociated pathogens. J Antimicrob Chemother 61: 651657.

Darouiche RO, Farmer J, Chaput C, Mansouri M, Saleh G, Landon GC (1998a) Anti-infective efficacy of antiseptic-coated intramedullary nails. J Bone Joint Surg Am 80: 1336-1340.

Darouiche RO, Green G, Mansouri MD (1998b) Antimicrobial activity of antiseptic-coated orthopaedic devices. Int J Antimicrob Agents 10: 83-86.

de Breij A, Riool M, Kwakman PHS, de Boer L, Cordfunke RA, Drijfhout JW, Cohen O, Emanuel N, Zaat SAJ, Nibbering PH, Moriarty TF (2016) Prevention of Staphylococcus aureus biomaterial-associated infections using a polymer-lipid coating containing the antimicrobial peptide OP-145. J Control Release 222: 1-8.

Drago L, Romanò D, De Vecchi E, Vassena C, Logoluso N, Mattina R, Romanò CL (2013) Bioactive glass BAG$\mathrm{S} 53 \mathrm{P} 4$ for the adjunctive treatment of chronic osteomyelitis of the long bones: an in vitro and prospective clinical study. BMC Infect Dis 13: 584.

Edmiston CE, Bruden B, Rucinski MC, Henen C, Graham MB, Lewis BL (2013) Reducing the risk of surgical site infections: does chlorhexidine gluconate provide a risk reduction benefit? Am J Infect Control 41: S49-S55.

Elek S, Conen P(1957) The virulence of Staphylococcus pyogenes for man. A study of the problems of wound infection. Br J Exp Pathol 38: 573-586.

Engelsman AF, Saldarriaga-Fernandez IC, Nejadnik MR, van Dam GM, Francis KP, Ploeg RJ, Busscher HJ, van der Mei HC (2010) The risk of biomaterial-associated infection after revision surgery due to an experimental primary implant infection. Biofouling 26: 761-767.

Fan X, Lin L, Messersmith PB (2006) Cell fouling resistance of polymer brushes grafted from Ti substrates by surface-initiated polymerisation: effect of ethylene glycol side chain length. Biomacromolecules 7: 2443-2448.

FDA (2007) Draft guidance for industry and FDA staff - premarket notification [510(k)] submissions for medical devices that include antimicrobial agents. $\mathrm{CDRH}$ 510: 1-18.

Foyet A, Wu TH, van der Ven L, Kodentsov A, de With $G$, van Benthem R (2009) Influence of mixing ratio on the permeability of water and the corrosion performance of epoxy/amine coated un-pretreated Al-2024 evaluated by impedance spectroscopy. Prog. Org. Coatings 64: 138-141.

Fuchs T, Stange R, Schmidmaier G, Raschke MJ (2011) The use of gentamicin-coated nails in the tibia: preliminary results of a prospective study. Arch Orthop Trauma Surg 131: 1419-1425.

Garcia FG, Elena Leyva M, Alencar de Queiroz AA, Zazuco Higa O (2009) Epoxy networks for medicine applications: mechanical properties and in vitro biological properties. J Appl Polym Sci 112: 1215-1225.

Garcia FG, Vicente TA, Queiroz AAA de, Higa OZ, Baratéla FJC (2016) Redes epóxi/amina alifáticas com perspectivas para aplicações cardiovasculares. propriedades biológicas in vitro. Matéria (Rio Janeiro) 21: 115-128.

Horner C, Mawer D, Wilcox M (2012) Reduced susceptibility to chlorhexidine in staphylococci: is it increasing and does it matter? J Antimicrob Chemother 67: 2547-2559.

Iqbal A (2012) Antimicrobial irrigants in the endodontic therapy. Int J Health Sci (Qassim). 6: 1-7.

Japanese Industrial Standards (2000) Antimicrobial products-test for antimicrobial activity and efficacy. Japanese Standards Association. JIS Z 2801.

Johnson RC, Schlett CD, Crawford K, Lanier JB, Merrell DS, Ellis MW (2015) Recurrent methicillinresistant Staphylococcus aureus cutaneous abscesses and selection of reduced chlorhexidine susceptibility during chlorhexidine use. J Clin Microbio. 53: 3677-3682.

Kälicke T, Schierholz J, Schlegel U, Frangen TM, Köller M, Printzen G, Seybold D, Klöckner S, Muhr G, Arens S (2006) Effect on infection resistance of a local antiseptic and antibiotic coating on osteosynthesis implants: An in vitro and in vivo study. J Orthop Res 24: 1622-1640.

Karpanen TJ, Casey AL, Whitehouse T, Nightingale P, Das I, Elliott TSJ (2016) Clinical evaluation of a chlorhexidine intravascular catheter gel dressing on shortterm central venous catheters. Am J Infect Control 44: 54-60.

Li D, Gromov K, Søballe K, Puzas JE, O’Keefe RJ, Awad H, Drissi H, Schwarz EM (2008) Quantitative mouse model of implant-associated osteomyelitis and the kinetics of microbial growth, osteolysis, and humoral immunity. J Orthop Res 26: 96-105.

van der Loos CM (2010) Chromogens in multiple immunohistochemical staining used for visual assessment and spectral imaging: the colorful future. J Histotechnol 33: $31-40$.

Lucke M, Schmidmaier G, Sadoni S, Wildemann B, Schiller R, Haas N., Raschke M (2003) Gentamicin coating of metallic implants reduces implant-related osteomyelitis in rats. Bone 32: 521-531.

Lynch M, Esser MP, Shelley P, Wroblewski BM (1987) Deep infection in charnley low-friction arthroplasty. Comparison of plain and gentamicin-loaded cement. J Bone Joint Surg 69: 355-360.

Maki DG (1997) Prevention of central venous catheterrelated bloodstream infection by use of an antisepticimpregnated catheter. A randomized, controlled trial. Ann Intern Med 127: 257-266. 
McDonnell G, Russell AD (1999) Antiseptics and disinfectants: activity, action, and resistance. Clin Microbiol Rev 12: 147-179.

Meis NNAH, van der Ven LGJ, van Benthem RATM, de With G (2014) Extreme wet adhesion of a novel epoxyamine coating on aluminum alloy 2024-T3. Prog Org Coatings 77: 176-183.

Moojen DJF, Vogely HC, Fleer A, Nikkels PGJ, Higham P a., Verbout AJ, Castelein RM, Dhert WJA (2009) Prophylaxis of infection and effects on osseointegration using a tobramycin-periapatite coating on titanium implants-An experimental study in the rabbit. J Orthop Res 27: 710-716.

Necula BS, Fratila-Apachitei LE, Zaat SAJ, Apachitei I, Duszczyk J (2009) In vitro antibacterial activity of porous TiO2-Ag composite layers against methicillin-resistant Staphylococcus aureus. Acta Biomater. 5: 3573-3580.

Nejadnik MR, Engelsman AF, Saldarriaga Fernandez IC, Busscher HJ, Norde W, van der Mei HC (2008) Bacterial colonisation of polymer brush-coated and pristine silicone rubber implanted in infected pockets in mice. $\mathrm{J}$ Antimicrob Chemother 62: 1323-1325.

Neut D, Dijkstra RJ, Thompson JI, Kavanagh C, van der Mei HC, Busscher HJ (2015) A biodegradable gentamicinhydroxyapatite-coating for infection prophylaxis in cementless hip prostheses. Eur Cell Mater 29: 42-55.

Nijhof MW, Dhert WJ, Fleer A, Vogely HC, Verbout AJ (2000) Prophylaxis of implant-related staphylococcal infections using tobramycin-containing bone cement. J Biomed Mater Res 52: 754-761.

O'Gara JP, Humphreys H (2001) Staphylococcus epidermidis biofilms: importance and implications. J. Med. Microbiol. 50: 582-587.

Odekerken JCE (2015) Orthopaedic infections: preclinical models, diagnostic tools and novel coatings. Ph.D. thesis; Maastricht University Medical Center, Maastricht, The Netherlands.

Pérez-Köhler B, García-Moreno F, Brune T, Pascual G, Bellón JM (2015) Preclinical bioassay of a polypropylene mesh for hernia repair pretreated with antibacterial solutions of chlorhexidine and allicin: an in vivo study. PLoS One 10: e0142768.

Riool M, de Boer L, Jaspers V, van der Loos CM, van Wamel WJB, Wu G, Kwakman PHS, Zaat SAJ (2014) Staphylococcus epidermidis originating from titanium implants infects surrounding tissue and immune cells. Acta Biomater 10: 5202-5212.

Romano CL, Logoluso N, Meani E, Romano D, De Vecchi E, Vassena C, Drago L (2014) A comparative study of the use of bioactive glass S53P4 and antibiotic-loaded calcium-based bone substitutes in the treatment of chronic osteomyelitis: a retrospective comparative study. Bone Joint J 96-B: 845-850.

Rooijakkers SHM, van Wamel WJB, Ruyken M, van Kessel KPM, van Strijp JAG (2005) Anti-opsonic properties of staphylokinase. Microbes Infect. 7: 476-484.

Shi Z, Neoh KG, Kang ET, Poh C, Wang W (2008) Bacterial adhesion and osteoblast function on titanium with surface-grafted chitosan and immobilized RGD peptide. J Biomed Mater Res Part A 86: 865-872.
Sjollema J, Dijkstra RJB, Abeln C, van der Mei HC, van Asseldonk D, Busscher HJ (2014) On-demand antimicrobial release from a temperature-sensitive polymer - comparison with ad libitum release from central venous catheters. J Control Release 188: 61-66.

Smeltzer MS, Thomas JR, Hickraon SG, Skinner RA, Nelson CL, Griffith D, Parr TR, Evans RP (1997) Characterisation of a rabbit model of staphylococcal osteomyelitis. J Orthop Res 15: 414-421.

Testai E, Hartemann P, Rodríguez-Farre E, Rastogi SC, Bustos J, Gundert-Remy U, Hensten A, Kopperud HM, Olea N, Piersma A, De Jong W (2016) The safety of the use of bisphenol A in medical devices. Regul Toxicol Pharmacol 79: 106-107.

Vuong C, Kocianova S, Yao Y, Carmody AB, Otto $M$ (2004) Increased colonisation of indwelling medical devices by quorum-sensing mutants of Staphylococcus epidermidis in vivo. J Infect Dis 190: 1498-1505.

Watson M a, Lyskawa J, Zobrist C, Fournier D, Jimenez M, Traisnel M, Gengembre L, Woisel P (2010) A "Clickable" titanium surface platform. Langmuir 26: 15920-15924.

Wilkins RG, Unverdorben M (2013) Wound cleaning and wound healing. Adv Skin Wound Care 26: 160-163.

Wu TH, Foyet A, Kodentsov A, van der Ven LGJ, van Benthem RATM, de With G (2014) Wet adhesion of epoxy-amine coatings on 2024-T3 aluminum alloy. Mater Chem Phys 145: 342-349.

Zaat S, Broekhuizen C, Riool M (2010) Host tissue as a niche for biomaterial-associated infection. Future Microbiol 5: 1149-1151.

Zimmerli W, Sendi P (2011) Pathogenesis of implant-associated infection: the role of the host. Semin Immunopathol 33: 295-306.

Zimmerli W, TrampuzA, Ochsner PE (2004) Prostheticjoint infections. N Engl J Med 351: 1645-1654.

\section{Web References}

1. Oldani C, Dominguez A (2012) Titanium as a biomaterial for implants. Intechopen.com.

2. ASTM A480: "Standard specification for general requirements for flat-rolled stainless and heat-resisting steel plate, sheet, and strip". https://www.astm.org/Standards/ A480.htm

3. ASTM D5402: "Standard practice for assessing the solvent resistance of organic coatings using solvent rubs". https://www.astm.org/Standards/D5402.htm

4. ASTM D3359: "Standard test methods for measuring adhesion by tape test". https://www.astm.org/Standards/ D3359.htm

\section{Discussion with Reviewers}

David Grainger: Do the authors envision this nondegrading coating to be used in limited, designated places on the implant, well-away from the cement-less bone ongrowth areas? How is this rationalised if infection often 
occurs where bone on-growth is also supposed to occur? Authors: Initial studies have indicated that the coating does not necessarily inhibit - or even promotes - bone apposition and might therefore also be used to prevent infection of bone on-growth areas of the implant.

David Grainger: Would be a possibility to use this approach with cemented implants, where antibiotic loaded cements might synergies chlorhexidine release? Often antibiotics are combined with antiseptics as the authors cite for catheters (rifampin/chlorhexidine), silver/minocycline, etc. So is this not appropriate to be used with antibiotic loaded cements?

Authors: This certainly is a possibility but it requires further investigation regarding the optimal combination of chlorhexidine and antibiotics. The combination of antiseptics and antibiotics is not that common though. The references cited have predominantly studied the use of either combinations of two antiseptics (e.g. chlorhexidine and silver-sulfadiazine; Maki, 1997) or of two antibiotics (e.g. rifampicin and minocycline; Darouiche, 2007).

Yannis Missirlis: What is the shear rate experience by the coating/substrate interface, when the artificial hip is forcefully inserted in place?

Authors: We are not aware of the exact shear rate in this particular case, as the present study was the first step in the development of a novel mechanically stable antimicrobialreleasing coating. Indeed, insertion of a prosthetic hip may be associated with greater shear rates, with possible consequences for any coating applied on the implant. Further research should focus on the possible applications of this coating.
Yannis Missirlis: Is fatigue shear to be experienced at the interface during everyday use of the implant?

Authors: Depending on the application, fatigue shear might be experienced at the interface (also see question above). Whether this would compromise the functionality of the implant in the long term requires further long term research in relevant animal models.

Yannis Missirlis: How much more does dopamine facilitate adhesion to Ti surfaces? Does the Ti surface have to be prepared for this purpose?

Authors: Dopamine facilitates adhesion because of its catechol moiety, being able to attach to the surface oxide layer of the titanium substrate (Ye et al., 2011). Apart from cleaning, the surfaces did not need any preparation to attain adhesion. However the increase in adhesion due to dopamine was not quantified during the coating design phase. Epoxy/amine coatings without dopamine (or an appropriate primer layer) detached from the metal substrates upon submersion in water.

\section{Additional references}

Ye Q, Zhou F, Liu W (2011) Bioinspired catecholic chemistry for surface modification. Chem Soc Rev 40: 4244-4258

Editor's note: The Scientific Editor responsible for this paper was Thomas Fintan Moriarty. 